\title{
MHC Class I Gene
}

National Cancer Institute

\section{Source}

National Cancer Institute. MHC Class I Gene. NCI Thesaurus. Code C16617.

A family of genes that encode major histocompatibility complex proteins and are involved in the presentation of cytoplasmic protein fragments to cytotoxic lymphocytes. 